\title{
ANALISIS FAKTOR-FAKTOR YANG MEMPENGARUHI PAJAK PENGHASILAN BADAN SEBAGAI INDIKATOR MANAJEMEN PERENCANAAN PAJAK PADA PERUSAHAAN SEKTOR MANUFAKTUR DI BURSA EFEK INDONESIA TAHUN 2013-2017
}

\author{
Petrus \\ Program Studi Magister Manajemen Universitas Tarumanagara \\ kevazlie16@gmail.com
}

\begin{abstract}
Abstrak : Tujuan penelitian ini adalah untuk menganalisa dan mengetahui 1) pengaruh Profitabilitas terhadap Efective Tax Rate 2) Intensitas Persediaan terhadap Efective Tax Rate 3) Intensitas Modal terhadap Efective Tax Rate 4) Leverage terhadap Efective Tax Rate. Populasi dalam penelitian ini adalah perusahaan sektor manufaktur yang terdaftar di Bursa Efek Indonesia selama periode tahun 2013-2017. Sampel yang digunakan pada penelitian ini yaitu 52 perusahaan pada semua sektor industri manufaktur sebagai subyek penelitian. Teknik pengambilan sampel yang digunakan yaitu Teknik Estimasi Data Panel. Secara keseluruhan hasil dari penelitian ini yaitu 1) Probabilitas mempengaruhi Effective Tax Rate memiliki arah negatif signifikan pada perusahaan manufaktur di Bursa Efek Indonesia pada tahun 2013-2017, 2) Intensitas Persediaan mempengaruhi Effective Tax Rate memiliki arah negatif namun tidak signifikan pada perusahaan manufaktur di Bursa Efek Indonesia pada tahun 2013-2017, 3 Intensitas Modal mempengaruhi Effective Tax Rate memiliki arah positif namun tidak signifikan pada perusahaan manufaktur di Bursa Efek Indonesia pada tahun 2013-2017, 4) Leverage mempengaruhi Effective Tax Rate memiliki arah negatif namun tidak signifikan pada perusahaan manufaktur di Bursa Efek Indonesia pada tahun 2013-2017.
\end{abstract}

Kata kunci : Effective Tax Rate, Return on Assets, Profitabilitas, Intensitas Modal, Intensitas Persediaan, Intensitas Modal, Leverage, Tax Avoidance, Perencanaan Pajak

\begin{abstract}
The purpose of this research is to analyse and find out 1) the effect of Profitability on the Effective Tax Rate 2) Inventory Intensity to the Effective Tax Rate 3) Capital Intensity to the Effective Tax Rate 4) Leverage to the Effective Tax Rate. The population in this study are manufacturing sector companies listed on the Indonesia Stock Exchange during the period 2013-2017. The sample used in this study is 52 companies in all industry sector of manufacturing as research subjects. The sampling technique used is the Panel Data Estimation Technique. Overall the results of this study are 1) The probability of influencing Effective Tax Rate has a significant negative direction on manufacturing companies on the Indonesia Stock Exchange in 2013-2017, 2) Inventory Intensity affects the Effective Tax Rate having a negative but not significant direction on manufacturing companies in the Exchange Indonesia Securities in 2013-2017, 3) Capital Intensity affects the Effective Tax Rate to have a positive but not significant direction in manufacturing companies on the Indonesia Stock Exchange in 20132017 , 4) Leverage affects Effective Tax Rate has a negative but not significant direction in manufacturing companies on the Indonesia Stock Exchange in 2013-2017.
\end{abstract}

Keywords : Effective Tax Rate, Return on Assets, Profitability, Inventory Intensity, Capital Intensity, Leverage, Tax Avoidance, Tax Plan

\section{PENDAHULUAN}

Menurut Statement of Financial Accounting Concept (SFAC) No. 1, informasi laba merupakan perhatian utama untuk menaksir kinerja atau pertanggungjawaban manajemen. Selain itu informasi laba juga membantu pemilik atau pihak lain dalam menaksir earnings 
power perusahaan di masa yang akan datang. Adanya kecenderungan lebih memperhatikan laba ini disadari oleh manajemen, khususnya manajer yang kinerjanya diukur berdasarkan informasi laba tersebut. Managemen laba dapat dilakukan dengan cara meningkatkan atau memaksimalkan pendapatan dan menurunan atau meminimalisasi biaya, salah satunya dapat dilakukan dengan meminimalisasi biaya pajak untuk mendapatkan laba bersih setelah pajak yang maksimal, untuk itu dibutuhkan manajemen pajak yang baik. Manajemen pajak memiliki peran yang sangat penting untuk perusahaan atau wajib pajak, selain sebagai usaha efisiensi untuk mencapai laba dan likuiditas yang diharapkan, managemen pajak juga bertujuan agar wajib pajak dapat menerapkan peraturan perpajakan secara benar, membayar pajak menurut hukum dan peraturan yang berlaku serta menghindari hal-hal yang tidak terduga yang dapat menyebabkan kerugian perusahaan atas hutang pajak maupun sanksi yang timbul dikemudian hari, baik sanksi administrasi maupun sanksi pidana. Karena kurangnya pengetahuan dalam hal managemen pajak, banyak wajib pajak melakukan penghematan pajak dengan cara yang tidak tepat atau penggelapan pajak (Tax Evasion), yang sebenarnya dapat dihindari dengan melakukan Tax Advoidance penghindaran pajak yang benar dan tidak melanggar peraturan perpajakan yang berlaku. Dalam sudut pandang perencanaan pajak, Tax Avoidance yang dilakukan oleh wajib pajak adalah sah dan secara yuridis sehingga tidak bisa ditetapkan pengenaan pajak. pengertian dari tax avoidance adalah upaya pengurangan utang pajak secara konstitusional (international tax glossary, 2005).

Perencanaan Pajak adalah suatu kapasitas yang dimiliki oleh wajib pajak (WP) untuk menyusun aktivitas keuangan untuk mendapat pengeluaran (beban) pajak yang minimal. secara teoritis, Perencanaan Pajak dikenal sebagai Effective Tax Planning, yaitu seorang wajib pajak berusaha mendapat penghematan pajak (tax saving) melalui prosedur penghindaran pajak (tax avoidance) secara sistematis sesuai ketentuan UU Perpajakan (Hoffman, 1961). Sebelum menerapkan tax planning pada suatu perusahaan harus dilakukan analisis keadaan perusahaan, yaitu melakukan pengamatan dan penelitian terhadap kebijaksanaan perusahaan serta mencari kelemahan sehingga dapat ditentukan strategi perencanaan perpajakan yang tepat dilaksanakan. Manajemen Perpajakan yang Ekonomis, Efisiensi, dan Efektif. Untuk dapat meminimalisasi kewajiban pajak, dapat dilakukan berbagai cara, baik yang masih memenuhi ketentuan perpajakan (lawful) maupun yang melanggar peraturan perpajakan (unlawful), seperti tax avoidance dan tax evasion. Pada dasarnya, perencanaan pajak harus memenuhi syarat-syarat berikut: (1) tidak melanggar ketentuan perpajakan, (2) secara bisnis dapat diterima, dan (3) bukti-bukti pendukungnya memadai. Manajemen pajak tidak dimaksudkan untuk melanggar peraturan dan jika dalam pelaksanaannya menyimpang dari peraturan yang berlaku, maka praktik tersebut telah menyimpang dari tujuan manajemen pajak. Untuk dapat mencapai tujuan manajemen pajak, ada dua hal yang perlu dikuasai dan dilaksanakan, yaitu memahami ketentuan peraturan perpajakan dan menyelenggarakan pembukuan yang memenuhi syarat atau sesuai Standar Akuntansi Keuangan yang berlaku. Manajemen pajak harus dilakukan dengan baik agar tidak menjurus kepada pelanggaran norma perpajakan atau penghindaran pajak. Perusahaan juga harus dapat memanfaatkan celah-celah yang ada dalam peraturan perpajakan. Untuk dapat melakukan perencanaan pajak, kita terlebih dahulu harus mengetahui faktor-faktor apa saja yang mempengaruhi besarnya Efective Tax Rate, beberapa faktor yang dapat dimaksimalkan oleh perusahaan untuk melakukan manajemen pajaknya antara lain Profitabilitas, Intensitas Persediaan, Intensitas Modal, dan Leverage.

\section{METODE PENELITIAN}

Populasi penelitian ini merupakan perusahaan sektor manufaktur yang terdaftar di Bursa Efek Indonesia selama periode tahun 2013-2017 total sebanyak 136 perusahaan. Metode yang digunakan dalam penelitian ini perihal dalam pengambilan sampel yaitu menggunakan nonprobability sampling dengan teknik purposive sampling. Dari seluruh data-data yang telah dikumpulkan telah dieliminasi dikarenakan tidak memenuhi kriteria yang ada sehingga 
terdapat 59 perusahaan yang memiliki dan memenuhi kriteria. Prosedur pemilihan sampel penelitian dapat dilihat pada table dibawah ini :

Tabel 1 Prosedur Pemilihan Sampel Penelitian

\begin{tabular}{|c|l|c|}
\hline No & \multicolumn{1}{|c|}{ Kriteria Sampel } & Jumlah \\
\hline 1 & $\begin{array}{l}\text { Perusahaan sektor manufaktur yang terdaftar di Bursa Efek Indonesia } \\
\text { selama periode 2013,2014, 2015, 2016, dan 2017 }\end{array}$ & 136 \\
\hline 2 & $\begin{array}{l}\text { Perusahaan sektor manufaktur yang tidak menerbitkan laporan } \\
\text { keuangan secara berturut-turut diBEI selama periode 2013,2014, } \\
2015,2016, \text { dan 2017 }\end{array}$ & -15 \\
\hline 3 & $\begin{array}{l}\text { Perusahaan sektor manufaktur yang tidak memperoleh laba selama } \\
\text { periode 2013,2014, 2015, 2016, dan 2017 }\end{array}$ & -57 \\
\hline 4 & $\begin{array}{l}\text { Perusahaan yang memiliki nilai ETR kurang dari nol atau minus atau } \\
\text { lebih bayar }\end{array}$ & -5 \\
\hline 5 & Jumlah data Outlier Jumlah Perusahaan & -7 \\
\hline & \multicolumn{2}{|c|}{ Jumlah Observasi } \\
\hline & $\quad$ & 260 \\
\hline
\end{tabular}

\section{HASIL DAN PEMBAHASAN}

Berikut ini disajikan hasil statistic deskriptif setiap variable dan hasil regresi dari penelitian sebagai hasil pengujian hipotesis :

Tabel 2 Hasil Uji Statistik Deskriptif

\begin{tabular}{|l|c|c|c|c|c|}
\hline & ETR & ROA & INVINT & CAPINT & DER \\
\hline Mean & 0.266192 & 8.402962 & 4.903500 & 0.349885 & 0.958692 \\
\hline Median & 0.250000 & 7.185000 & 4.330000 & 0.320000 & 0.690000 \\
\hline Maximum & 0.710000 & 39.48000 & 18.69000 & 0.910000 & 7.400000 \\
\hline Minimum & 0.010000 & 0.100000 & 0.300000 & 0.030000 & 0.030000 \\
\hline Std. Dev. & 0.090262 & 6.626096 & 2.689291 & 0.157964 & 0.955789 \\
\hline Skewness & 1.472060 & 1.631234 & 1.361545 & 0.646914 & 3.260643 \\
\hline Kurtosis & 7.658082 & 6.604942 & 6.282903 & 2.874929 & 16.98660 \\
\hline Observations & 260 & 260 & 260 & 260 & 260 \\
\hline
\end{tabular}

Sumber : Data diperoleh dari Eviews 9.0

\begin{tabular}{crrrr}
\multicolumn{7}{c}{ Tabel 3 Hasil Uji Hipotesis } & \\
Variable & Coefficient & Std. Error & t-Statistic & Prob. \\
\hline \hline ROA & -0.006746 & 0.000670 & -10.06852 & 0.0000 \\
INVINT & 0.005197 & 0.001919 & 2.708360 & 0.0073 \\
CAPINT & 0.013568 & 0.022939 & 0.591512 & 0.5548 \\
DER & 0.005762 & 0.006728 & 0.856525 & 0.3927 \\
C & 0.287123 & 0.015754 & 18.22548 & 0.0000 \\
\hline \multicolumn{5}{c}{ Effects Specification } \\
\hline \hline \multicolumn{5}{c}{ Cross-section fixed (dummy variables) } \\
\hline \hline R-squared & Weighted Statistics \\
Adjusted R-squared & 0.691404 & Mean dependent var & 0.616133 \\
S.E. of regression & 0.608204 & S.D. dependent var & 0.582303 \\
F-statistic & 0.070686 & Sum squared resid & 1.019284 \\
Prob(F-statistic) & 8.310138 & Durbin-Watson stat & 2.412611 \\
\hline \hline & 0.000000 & \\
\hline \hline
\end{tabular}

Sumber : Data diperoleh dari Eviews 9.0 


\section{Profitability terhadap Pajak Penghasilan (Effective Tax Rate)}

Profitabilitas merupakan salah satu pengukuran bagi kinerja suatu perusahaan. Profitabilitas adalah ukuran kemampuan perusahaan perseorangan atau badan untuk menghasilkan laba dengan memperhatikan modal yang digunakan. Pengukuran efektifitas pengelolaan sumber daya perusahaan dengan pendapatan yang diterima, dapat diukur dengan dengan menghitung pendapatan yang dihasilkan dengan total asset yang ada didalam perusaahaan. Salah satunya dikenal sebagai rasio profitabilitas adalah Return on Assets (ROA) yaitu rasio profitabilitas yang dapat membandingkan laba bersih dengan total aset pada akhir periode, yang digunakan sebagai indikator kemampuan perusahaan dalam menghasilkan laba. ROA digunakan karena dapat memberikan pengukuran yang memadai atas keseluruhan efektifitas perusahaan dan dapat memperhitungkan profitabilitas. Pada dasarnya Laba yang semakin tinggi menyebabkan meningkatnya tarif pajak efektif pada perusahaan sehingga semakin tinggi profitabilitas membuat manajemen pajak semakin buruk (Darmadi, 2013). Semakin rendah tarif pajak efektifnya maka semakin efisien manajemen pajak perusahaan tersebut. Perusahaan dapat meminimalkan tarif pajak efektif dengan membelanjakan laba yang diperoleh untuk hal-hal yang bermanfaat dan bersifat deductible bagi perusahaan. Bisa juga melalui penghasilan bukan objek pajak dan final yang menjadi pengurang dalam perhitungan penghasilan kena pajak. Sesuai dengan hasil penelitian yang dilakukan Steffi \& Meiriska (2017) Profitabilitas berpengaruh negatif terhadap Effective Tax Rate. Hasil regresi yang didapatkan dalam penelitian ini menunjukan angka probabilitas yang sangat signifikan untuk variable Profitability yaitu sebesar 0.0000 atau $>0.05$

H1 Profitability berpengaruh negatif terhadap Pajak Penghasilan (Effective Tax Rate)

\section{Intensitas Persediaan terhadap Pajak Penghasilan (Effective Tax Rate)}

PSAK No. 14 (revisi 2008) mengatur biaya yang timbul atas kepemilikan persediaan yang besar harus dikeluarkan dari dari biaya persediaan dan diakui sebagai beban dalam periode terjadinya biaya. Biaya tambahan atas adanya persediaan yang besar akan menyebabkan penurunan laba perusahaan dan penurunan pajak penghasilan atau Effective Tax Rate.Sesuai dengan hasil penelitian yang dilakukan Citra \& Maya (2016) bahwa Intesitas Persediaan berpengaruh negatif terhadap Effective Tax Rate. Namun pada umumnya perusahaan Manufaktur yang memiliki persediaan barang dagang cukup besar dan diimbangi dengan nilai penjualan yang jauh lebih besar daripada harga pokok penjualan sehingga dapat menyebabkan peningkatan intensitas persediaan yang juga secara tidak langsung dapat meningkatkan laba dan menyebabkan kenaikan nilai pajak penghasilan (ETR), sesuai dengan hasil penelitian ini mendapatkan hasil probabilitas yang signifikan sebesar 0.0073 atau $>0.05$ yang berarti intensitas persediaan berpengaruh positif terhadap Effective Tax Rate. Didukung dengan penelitian terdahulu berdasarkan jurnal internasional yang dikutip, G. Richardson \& Roman Lanis (2007) dan juga Elena Fernández-Rodríguez \& Antonio Martínez-Arias (2012) menunjukan bahwa Inventory Intensity berpengaruh positif terhadap Effective Tax Rate. H2 Intensitas Persediaan berpengaruh positif terhadap Pajak Penghasilan (Effective Tax Rate)

\section{Intensitas Modal terhadap Pajak Penghasilan (Effective Tax Rate)}

Rodriguez dan Arias (2012) dalam Ardyansah (2014) mengatakan bahwa aset tetap perusahaan memungkinkan perusahaan untuk mengurangi pajaknya akibat dari penyusutan yang muncul dari aset tetap setiap tahunnya. Hal ini karena beban penyusutan aset tetap ini secara langsung akan mengurangi laba perusahaan yang menjadi dasar perhitungan pajak perusahaan. Intensitas modal memiliki hubungan yang negative dengan ETR (Richardson dan Lanis, 2007). Menurut Hanum (2013) biaya depresiasi dapat dikurangkan dari penghasilan dalam menghitung pajak, maka semakin besar aset tetap yang dimiliki perusahaan mengakibatkan depresiasi yang besar juga sehingga mengakibatkan jumlah penghasilan kena pajak dan ETR nya berkurang. Namun berbeda dengan hasil penelitian ini dimana ditemukan 
pengaruh negatif antara intesitas modal terhadap effectie tax rate walaupun nilainya tidak signifikan, karena rasio intesitas modal(CAPINT) dipengaruhi juga oleh nilai aktiva lainnya seperti aktiva lancar dimana jika penambahan nilai aktiva lancar/lainnya tidak diimbangi dengan penambahan nilai aktiva tetap akan membuat rasio semakin kecil dan dapat sebanding dengan penurunan nilai pajak penghasilan sehingga didapatkan hasil pengaruh yang positif. Hubungan nonlinear ini dapat dijelaskan oleh hasil yang ditemukan oleh beberapa peneliti hubungan positif antara CAPINT dan ETR atau tidak ada hubungan di antara mereka. Hasil penelitian yang berbeda-beda merupakan hal yang wajar karena proxy intensitas modal ini sangat dipengaruhi oleh nilai asset lainnya, seperti hasil regresi yang didapatnya dalam penelitian ini dengan nilai probabilitas sebesar 0.5548 atau $<0.05$ yang menunjukan pengaruh yang tidak signifikan, demikian juga penelitian yang dilakukan pada perusahaan manufaktur sebelumnya oleh Steffi \& Meiriska (2017) Intensitas Persediaan tidak berpengaruh terhadap Managemen Pajak.

H3 Intensitas Persediaan tidak berpengaruh terhadap Pajak Penghasilan (Effective Tax Rate)

\section{Leverage terhadap Pajak Penghasilan (Effective Tax Rate)}

Perusahaan dimungkinkan menggunakan utang untuk memenuhi kebutuhan operasional dan investasi perusahaan. Akan tetapi, hutang akan menimbulkan beban tetap (fixed rate of return) yang disebut dengan bunga. Semakin besar utang maka laba kena pajak akan menjadi lebih kecil karena insentif pajak atas bunga utang semakin besar. Perusahaan dapat menggunaakn tingkat leverage untuk mengurangi laba dan akan berpengaruh terhadap berkurangnya beban pajak (Brigham \& Houston, 2010). Leverage berpengaruh negatif terhadap Effective tax rate sesuai juga dengan beberapa penelitian sebelumnya salah satunya G. Richardson, Roman Lanis (2007).

Namun jika hutang yang diberikan dapat dimanfaatkan secara baik untuk meningkatkan produktifitas dan peningkatan laba perusahaan sehingga tidak begitu berpengaruh dengan adanya penambahan biaya bunga yang dibebankan akibat penambahan hutang tersebut. Dan juga Direktorat Jendral Pajak telah membatasi jumlah biaya bunga atas hutang yang dapat dibebankan sebagai biaya pajak sesuai 169/PMK.010/201. Besarnya perbandingan antara utang dan modal ditetapkan paling tinggi sebesar empat dibanding satu (4:1), dengan batasan tersebut besaran utang lebih dari $80 \%$ tidak bisa dibebankan sebagai biaya(dikoreksi fiskal) kecuali wajib pajak tertentu seperti Lembaga pembiayaan, Bank, Asuransi dan Reasuransi, wajib pajak yang menjalankan usaha dibidang pertambangan minyak dan gas bumi, pertambangan umum, dan pertambangan lainnya yang terikat kontrak bagi hasil, kontrak karya, atau perjanjian kerjasama pengusahaan pertambangan, dan dalam kontrak atau perjanjian dimaksud mengatur atau mencantumkan ketentuan mengenai batasan perbandingan antara utang dan modal dan wajib pajak yang atas seluruh penghasilannya dikenai pajak penghasilan yang bersifat final berdasarkan peraturan perundang-undangan tersendiri dan wajib pajak yang menjalankan usaha dibidang insfrastruktur. Ketentuan ini berlaku mulai berlaku sejak Tahun Pajak 2016. Leverage menunjukan nilai probabilitas 0.3927 atau > sig 0.05 sehingga hasil penelitian menyatakan Leverage tidak berpengaruh secara signifikan terhadap pajak penghasilan (Effective Tax Rate). Demikian juga penelitian yang dilakukan pada perusahaan manufaktur sebelumnya oleh Steffi \& Meiriska (2017) Intensitas Persediaan tidak berpengaruh terhadap Managemen Pajak dan juga didukung penelitian oleh I Gede Hendy Darmawan \& I Made Sukartha (2014).

H4 Leverage tidak berpengaruh terhadap Pajak Penghasilan (Effective Tax Rate)

\section{Kesimpulan}

Berdasarkan analisis dan pembahasan yang telah diuraikan, maka kesimpulan yang dapat diambil dari penelitian ini adalah sebagai berikut: 
1. Probabilitas mempengaruhi Effective Tax Rate memiliki arah negatif signifikan pada perusahaan manufaktur.

2. Intensitas Persediaan mempengaruhi Effective Tax Rate memiliki arah positif pada perusahaan manufaktur.

3. Intensitas Modal tidak berpengaruh signifikan terhadap Effective Tax Rate memiliki arah positif pada perusahaan manufaktur.

4. Leverage tidak berpengaruh signifikan terhadap Effective Tax Rate memiliki arah positif pada perusahaan manufaktur.

Perusahaan harus memperhatikan faktor-faktor yang menjadi acuan untuk dapat mempengaruhi Effective Tax Rate. Peneliti berharap penelitian ini dapat dikembangkan dengan penambahan variabel yang belum diuji dan proksi yang digunakan untuk mengukur pengaruh terhadap Effective Tax Rate dan dapat dijadikan perbandingan dan menyimpulkan apakah dengan adanya perbedaan indikator penelitian akan menghasilkan hal yang berbeda.Penelitian selanjutnya juga diharapkan jika bisa dapat juga menggunakan data premier dan diuji secara kualitatif juga, karena banyak variabel lain yang mempengaruhi besarnya beban pajak penghasilan yang tidak dapat diuji dengan menggunakan data sekunder secara kualitatif.

\section{DAFTAR PUSTAKA}

Ardyansah (2014). Pengaruh Size, Leverage, Profitability, Capital Intensity Ratio Dan Komisaris Independen Terhadap Effective Tax Rate (Etr). (Studi Empiris pada Perusahaan Manufaktur yang Terdaftar Di BEI Selama Periode 2010-2012). The 1st Accounting And Busines, Faculty Of Economic University Of Diponegoro, Semarang.

Dennis, Sundvik.2016. Book-Tax Conformity and Earnings Management in Response to Tax Rate Cuts. Journal of International Accounting, Auditing and Taxation

Frank, M., Lynch, L., dan Rego, S.2009. Tax reporting aggressiveness and its relation to aggressive

G. Taylor, G. Richardson / The International Journal of Accounting 47 (2012) $469-496$

Gujarati, N.D. 2003. Basic Econometrics. 4th ed. New York: McGraw-Hill Companies, Inc.

Ida Ayu Rosa Dewinta dan Putu Ery Setiawan.2016. Pengaruh Ukuran Perusahaan, Umur

Perusahaan, Profitabilitas, Leverage dan Pertumbuhan Penjualan Terhadap Tax advoidance. E-Jurnal Akuntansi Universitas Udayana

Ida Bagus Putu Fajar Adisamaratha dan Nanik Noviari.2015. Pengaruh Likuiditas, Leverage, Intensitas Persediaan, dan Intensitas Aset Tetap pada Tingkat Agresivitas Wajib Pajak Badan.

John R. Graham, Michelle Hanlon, Terry Shevlin, Nemit Shroff. 2013. THE ACCOUNTING REVIEW. Vol. 89, No. 3,PP 991-1023

Krisnata Dwi Suyanto \& Supramono.2012. Likuiditas, Leverage, Komisaris Independen, dan Manajemen Laba Terhadap Agresivitas Pajak Perusahaan

Kurniasih, Tommy dan Maria M. Ratna Sari. 2013. Pengaruh Return Turn On Asset (ROA), Leverage, Corporate Governance, Ukuran Perusahaan dan Kompensasi rugi Fiskal pada Tax Avoidance. Buletin Studi Ekonomi, 18(1): h:58-66

Peraturan Menteri Keuangan Republik Indonesia Nomor 169/PMK.010/2015

Rodriguez dan Arias (2012). Do Bussines Characteristics Determine An Effective Tax Rate, The Chinese Economy, 60 - 83

Surbakti, Theresa Adelina Victoria. 2012. Pengaruh Karakteristik Perusahaan dan Reformasi Perpajakan Terhadap Penghindaran Pajak di Perusahaan Industri Manufaktur Yang Terdaftar di Bursa Efek Indonesia Tahun 2008-2010.Skripsi Fakultas Ekonomi. Universitas Indonesia 
Turyatini.2017. The Analysis of Tax Avoidance Determinant on The Property and Real Estate Companies. Jurnal Dinamika Akuntansi, 9(2), 143-153.

Undang-Undang Republik Indonesia Nomor 17 Tahun 2000 Tentang Perubahan Ketiga Atas Undang-Undang Nomor 7 Tahun 1983 Tentang Pajak Penghasilan.

Undang-Undang Republik Indonesia Nomor 36 Tahun 2008 Tentang Perubahan Keempat Atas UndangUndang Nomor 7 Tahun 1983 Tentang Pajak Penghasilan.

Yoehana (2013). Analisis Pengaruh Corporate Social responsibility Terhadap Agresivitas pajak (Studi Empiris pada Perusahaan Manufaktur yang Terdaftar di Bursa Efek Indonesia Tahun 2010-2011. The 1st Accounting And Business, Faculty Of Economic University Of Diponegoro, Semarang 